UDK: $336.71(497-15)$

DOI: $10.2478 /$ jcbtp-2021-0012
Journal of Central Banking Theory and Practice, 2021, 2, pp. 23-37

Received: 07 December 2020; accepted: 29 December 2020

\author{
Nikola Milović ${ }^{*}$, Mijat Jocović ${ }^{* *}$, \\ Nikola Martinović ${ }^{* * *}$
}

\section{Analysis of the Impact of Macroeconomic Stability on the Level of Global Competitiveness of Western Balkan Countries}

\begin{abstract}
Competitiveness, as a complex concept, can be observed in different ways, from the perspective of an individual, group, company and/or state. The subject of this paper deals with competitiveness of national economies observed through factor analysis, with a particular focus on the level of macroeconomic stability. Through the application of the Analytical-Hierarchical Process (AHP) method, special attention has been paid to the comparative ranking of Western Balkan countries. The ranking has been made in relation to macroeconomic stability and the positions of countries in the ranking of the World Economic Forum, based on the Global Competitiveness Index, for three defined periods of time. The paper identifies key factors that affect the competitiveness of Western Balkan countries. Research findings show that macroeconomic stability has a strong impact on the level of global competitiveness of national economies.
\end{abstract}

Key words: global competitiveness, macroeconomic stability, national economy, GCI, Western Balkans

JEL classifications: E02, E60, E66, F01, O11, P20, P24.

\section{Introduction}

The history of economic thought shows that the wealth of the state and competitiveness have been the subject of interest of many economists since the time of mercantilism
${ }^{*}$ Faculty of Economics,

University of Montenegro,

Podgorica, Montenegro

Email:

nmilovic@ucg.ac.me

${ }^{* *}$ Faculty of Economics,

University of Montenegro,

Podgorica, Montenegro

Email:

mijatj@ucg.ac.me

${ }^{* * *}$ Faculty of Economics, University of Montenegro, Podgorica, Montenegro

Email:

nikola.m@ucg.ac.me 
(Milović, 2012). Today in the modern economy, the competitiveness of the state is influenced by a number of factors that collectively define the level of global competitiveness that the state achieves over a period of time (Safiullin, Elshin \& Prygunova, 2015). This scientific paper seeks to contribute to the analysis of this complex concept at the level of national economies.

The paper deals with the causal relationship that exists between macroeconomic stability and the level of global competitiveness of national economies. The research is related to the regional context of the Western Balkan countries. The analysis of the competitiveness of developing countries in the previous period comprised all the factors that affect competitiveness (Sanfey, Milatovic \& Kresic, 2016), however, the impact that macroeconomic stability has on achieving global competitiveness position has not been considered in isolation (ceteris paribus). Accordingly, the aim of this paper is to analyse the impact on the competitiveness of national economies through the analysis of the macroeconomic stability of the Western Balkan countries.

The concept of competitiveness can be analysed in different ways, with a central focus on achieving a higher standard of living and quality of life for citizens with high rates of economic growth. One of the most significant factors affecting economic growth rates and the level of global competitiveness, especially in developing countries, is macroeconomic stability (Vasylieva, Lyeonov, Lyulyov \& Kyrychenko, 2018).

Macroeconomic stability is the third pillar of the Global Competitiveness Index (GCI). In the literature it is described as a necessary but not sufficient condition for achieving a better competitiveness position (Mankiw, 2014). In marketoriented economies, economic growth rates depend on effective demand, and its existence in the long run depends primarily on the level of macroeconomic stability in the national economy (Jespersen, 2016). This reflects the specific nature of macroeconomic stability because it plays a key role in achieving higher growth rates, which is especially important for countries in the process of transition from the social to the market system of the economy (Snowdon \& Vane, 2005) which are primarily Western Balkan countries

Regardless of the fact it was in the use before, the term Western Balkans was first found in official documents of the European Union at the EU Summit in Vienna in 1998 (Topuzovski, 2009). An important determinant of this region is that unlike the countries of Central and Eastern Europe, a part related to the stabilization process was added to the Western Balkans in the process of accession to the European Union. This means, in particular, that the countries of this region 
need to first achieve stable and high-quality mutual cooperation, so that they can ultimately enter the process of a more dynamic EU accession process (Đurović, 2012). This is especially important because these are specific transition economies that went through great political instability at the end of the last century, which had an impact on the lower level of competitiveness of national economies.

The Analytical-Hierarchical Process (AHP) method is one of the most commonly used decision-making methods, which involves making decisions based on multiple attributes which are used as criteria (Dragašević, 2015). In order to rank certain performances by quality, it is a tool that is very often used in scientific research (Jovanović, Filipović \& Bakić, 2015). Collecting the necessary data on macroeconomic performance indicators of national economies through the use of the "Decision" program has resulted in the ranking of Western Balkan countries in terms of macroeconomic stability. In this paper, the results obtained will be put in the context of the competitiveness ranking of the World Economic Forum (WEF) in three defined points of time - 2009, 2013, and 2017.

\section{Theoretical background}

In practice, there is no single concept for determining competitiveness nor a defined approach that can be said to be a priori relevant. Accordingly, Siggel (2006) first divides the concepts for measuring competitiveness at the macro and micro levels, and later, by special analysis, shapes the structure of each (Stojčić, 2012). National competitiveness, as a phrase, is etymologically difficult to define and place in economic frameworks. At an earlier stage in the development of a society dominated by classical economists Smith and Ricardo, the differences that existed were explained solely by natural factors such as land, labour and capital. Some scholars (Krugman, 1994) even consider that there is no way to link competitiveness as a concept to national economies, but that it exists only between enterprises. The differences between countries in terms of development, citizens' standard of living, and global quality of life show the opposite.

Today, however, the prevailing opinion is that the competitiveness of a country is not only the result of natural factors but also of strategic decisions made by the power holders in national economies. This was supported by the statement of Michael Porter, who emphasizes that national competitiveness is created, not inherited (Porter, 1990). A special approach to competitiveness analysis is also given by Scott \& Lodge, who note that national competitiveness is a kind of tradeoff between achieving a better global position and social goals (Buckley, Pass \& Prescott, 1988). 
Today, competitiveness of national economies can be defined in different ways. Accordingly, there are several definitions of relevant institutions that prevail in theory and practice to date. Thus, the Organisation for Economic Co-operation and Development (OECD) defines competitiveness as the ability of a state to produce goods and services that pass the international market test in free and equitable market conditions while increasing real household income. The World Economic Forum (WEF), as an organisation that has been measuring the competitiveness of countries since 1979 by analysing various factors, as compiled in the Global Competitiveness Index (GCI), defines competitiveness as a set of institutions, policies, and factors that determine a country's level of productivity. The European Commission explains competitiveness through the concept of a high and rising standard of living for countries which is at the same time followed by a low level of unemployment.

The U.S. President's Commission on Industrial Competitiveness defines the competitiveness of the state as the ability to produce, under equitable and fair market, goods and services that pass the international market test while achieving longterm sustainable growth and increasing the standard of living of the population (Khalil \& Ezzat, 2001).

On the other hand, the literature analysing macroeconomic stability, emphasizes its specific nature in that it affects all countries irrespective of the level of development achieved up to a certain point in time, and that it requires the attention of economic authorities of both national and international institutions (Snowdon \& Vane, 2005). Macroeconomic instability has a negative impact on the operations of businesses and acts as a disincentive to foreign investors. Macroeconomic reality also significantly affects the stability of the financial sector (Kozarić, Žunić \& Dželihodžić, 2020). Achieving and maintaining macroeconomic stability is therefore one of the main tasks for power holders in every economy (Corsetti, Kuester, Meier \& Müller, 2013).

The most important macroeconomic indicators, which are also part of the third pillar of the GCI, are the following: level of public debt, national savings rate, inflation rate, budget deficit/surplus and country's credit rating. Each of them individually determines the level of macroeconomic stability. As such, we cannot observe them in isolation. Consequently, the budget deficit, like a spiral leads to higher interest rates on government loans, lowers the country's credit rating, and leads to rising inflation and public debt (Risti, Nicolaescu \& Tăgăduan, 2013).

Furthermore, the research conducted confirm the high level of correlation that exists between the national savings rate and the level of economic growth achieved 
by the state. The research indicate that the existence of this correlation is equally present in both developed and developing countries (Misztal, 2011). In terms of inflation, unwanted price increases mean an increase in raw materials, as well as dependent procurement costs. This acts as a disincentive, slows down the growth of the economy and state is perceived as an unfavourable environment for business development (Salman, 2014). If there is harmony in the country in terms of macroeconomic indicators and money security, then more foreign investors will be interested in placing their money.

Also study done in collaboration with the International Monetary Fund and based on data from over a hundred countries around the world, found that there was a high level of positive correlation between the country's credit rating and the level of invested funds through foreign direct investment over a period of time (Vijayakumar, Rasheed \& Tondkar, 2009). Public debt, if it exceeds the Maastricht criteria (EU, 1993), has a negative impact on overall macroeconomic stability and on the level of global competitiveness. This is also noticeable when, in the years following the Global economic crisis, instability occurred within the EU itself and its member states, and it raises the question of whether the Union itself is responding to the challenges posed by public debt (Kersan-Skabic, 2017).

In the part of the literature related to decision-making methods, it is stated that the majority of classical optimization methods used, in fact, have only one criterion when deciding or solving a particular problem (Čupić \& Rao, 2003). However, the question arises as to what the real essence of a problem that can be solved in this way is, given that solving a problem in real life is far from a simple linear function that depends on only one indicator (Bouzon, Govindan, Rodriguez \& Campos, 2016). It is precisely because of the complexity of the problem that is being analysed, and based on the defined macroeconomic stability indicators, that the AHP model was designed in this paper through the "Decision" program, which ranks Western Balkan countries.

\section{Macroeconomic stability and the level of global competitiveness of the Western Balkan countries}

Methodologically speaking, the AHP multicriteria analysis method is based on decomposing a complex problem within a hierarchy. The goal is at the top of the hierarchy, while the criteria, sub-criteria and alternatives are at the lower levels. In this particular case, the aim to be achieved is to rank Western Balkan countries. This ranking will be made through defined macroeconomic stability criteria. Kosovo is not included in the construction of the model itself due to the 
fact that it is not part of the World Economic Forum ranking list. The model is shown in Graph 1.

\section{Graph 1: Construction of AHP model for Western Balkan countries}

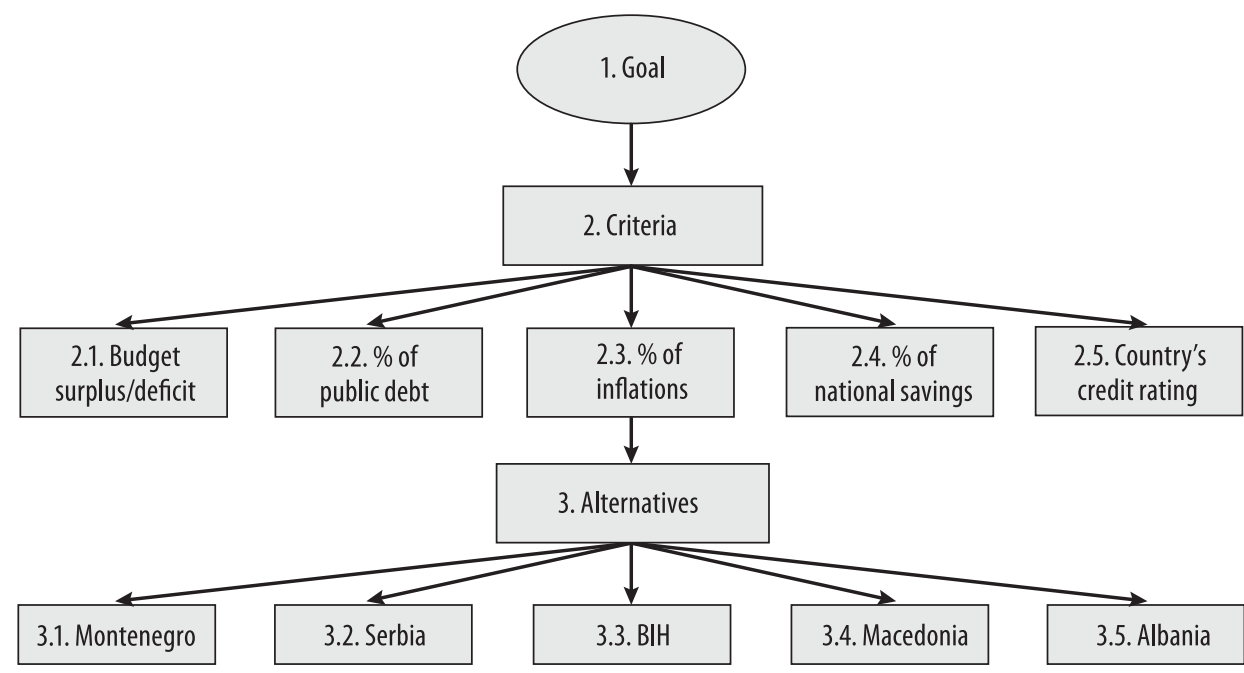

Source: Constructed model in "Decision" program

The next step is to evaluate the macroeconomic stability criteria by relevance. This means that it is necessary to add a specific parameter to each criteria or define its significance. For this purpose, a Saaty's scale was used, which takes values from 1 to 9, depending on the importance given to each of the criteria (Wind \& Saaty, 1980). (See Appendix 1).

After constructing the model, and defining the final results through the use of the "Decision" program, the final ranking lists were formed for three defined periods of time - 2009, 2013, 2017. See Appendix 2.

The fact is that each of the observed periods is specific in terms of global economic trends. Namely, 2009 was the year when the Global economic crisis was in the initial stages. At both national and supranational levels, some adjustments have been made to respond to the emerging challenge properly (Krugman, 2018). Nevertheless, these are still the moments when most countries achieve relatively good economic performance owing to the accumulation of results of positive economic developments in previous years. The continued crisis has negatively affected all countries of the world, including countries of the Western Balkans. Therefore, in the next analysed overview, most countries in the region faced se- 
rious problems with regard to macroeconomic indicators. This has resulted in the entry into force of fiscal consolidation programs, at national and supranational level (Kickert \& Randma-Liiv, 2015). Adequate fiscal policy can amortize the negative consequences of financial crises (Dumičić, 2019), therefore the third analysed point of time is significant because it monitored the successful implementation of the defined projects.

After obtaining the results, the last step is to carry out a comparative analysis of the results of the Western Balkan countries in terms of macroeconomic stability, and the positions countries of the region occupy on the WEF ranking list according to the GCI methodology. The results obtained are shown in Table 1.

Table 1: GCl and AHP -Western Balkan countries

\begin{tabular}{|c|c|c|c|c|c|c|}
\hline Country & $\begin{array}{c}\text { Rank AHP } \\
\text { method } \\
(2009)\end{array}$ & $\begin{array}{l}\text { GCI Rating } \\
\text { (2009) }\end{array}$ & $\begin{array}{c}\text { Rank AHP } \\
\text { method } \\
(2013)\end{array}$ & $\begin{array}{l}\text { GCI Rating } \\
\quad(2013)\end{array}$ & $\begin{array}{c}\text { Rang AHP } \\
\text { method } \\
(2017)\end{array}$ & $\begin{array}{l}\text { GCI Rating } \\
\text { (2017) }\end{array}$ \\
\hline Montenegro & 1 & 62 & 1 & 67 & 3 & 77 \\
\hline Macedonia & 2 & 84 & 2 & 73 & $x$ & $x$ \\
\hline $\begin{array}{l}\text { Bosnia and } \\
\text { Hercegovina }\end{array}$ & 3 & 109 & 3 & 87 & 4 & 95 \\
\hline Serbia & 4 & 93 & 5 & 101 & 1 & 78 \\
\hline Albania & 5 & 96 & 4 & 95 & 2 & 75 \\
\hline
\end{tabular}

Source: Global Competitiveness Report and Results of conducted model in "Decision" program

In the first observed overview, Montenegro and Macedonia achieved the best results within the AHP multicriteria analysis method and were at the same time ranked best in the WEF competitiveness rankings. Serbia was listed ahead of Albania in both alternatives, with the only change being Bosnia and Herzegovina, which is ranked third in the macroeconomic performance analysis, while occupying the last position in the World Rankings. Despite the aforementioned rotation, the above results support the view that macroeconomic stability and the results achieved in this area have an impact on the level of global competitiveness of the national economies of Western Balkan countries. While there is one discrepancy in the first overview, in the second overview the situation is mirrored when the results achieved are compared. Namely, the order of countries is identi$\mathrm{cal}$ in the AHP method rankings, and in the WEF rankings. In both alternatives, Montenegro came in first, Macedonia second, Bosnia and Herzegovina third, Albania fourth, and Serbia fifth. 
This confirms the fact that the determinants of macroeconomic stability are one of the key indicators of the level of global competitiveness achieved by the national economy. The third overview, which is specific in terms of the ranking of the four countries, makes small discrepancies when comparing the ranking of countries on the basis of the two observed aspects. Serbia, Albania, and Montenegro have partially rotated positions. The fact is that the differences between these countries in the WEF rankings are insignificant. The conducted analysis showed even smaller differences within the implemented AHP method by the "Decision" program.

Continued analysis required the identification of key factors that determined the macroeconomic indicators and the global competitiveness of the Western Balkan economies. The macroeconomic indicators of the countries in the region in the previous decade were not at an enviable level, that is, they tended to deteriorate from solid results in the years before the global economic crisis.

The problem is compounded due to the fact that not only economic factors were the cause of the poorer macroeconomic performance, but also numerous political developments and tensions in the region. As many as four Western Balkan countries have had serious political problems that have had a direct negative impact on the macroeconomic performance of the economy. This primarily refers to Serbia and Kosovo and the unresolved territorial issue, which both slow down the economic progress and membership process of both countries in international organizations (Woehrel, 2011). Macedonia, and until recently unresolved, a decades-long name dispute with Greece, has also been a burden, not only for affected countries, but for the whole region (Reuter, 1999). Bosnia and Herzegovina is in greater trouble because of the high level of dysfunction that exists in an ethnically divided country without a dominant national majority. These problems have a negative impact on the inflow of foreign investments, which is one of the main sources of economic growth in developing countries (Rice, 2017; Jocović, Milović \& Melović, 2016).

Each of the countries in the region is facing a lack of effective public administration. The excess labour force in the government apparatus puts a heavy burden on public finances and leads to an increase in the budget deficit. Improving the quality of the public financial management is also one of the preconditions for better cooperation with the European Union (Vukčević \& Jovović, 2020). Tax evasion has a markedly negative impact through reducing the amount of funds on the revenue side of the budget (Risteski, 2009). As a consequence, budget deficit occurs and countries in the region are often indebted for current spending, which lacks long-term sustainable economic logic and foundation (Milenković, Kalaš \& 
Andrašić, 2017). In a kind of spiral, this leads to a rise in public debt and a weak country's credit rating.

\section{Discussion and conclusion}

In order to establish a functioning market economy, it is necessary to continuously achieve results within the factors that affect competitiveness. This is especially important for countries that are in the process of building a market mechanism such as Western Balkan countries. One of the indicators along the way is the achievement of results in the field of macroeconomic stability.

Macroeconomic stability has a significant impact on the level of global competitiveness of the Western Balkan countries. The empirical research conducted involved the application of the AHP multicriteria analysis method and the ranking of Western Balkan countries in terms of macroeconomic stability in three observed periods of time (2009, 2013 and 2017). Comparative analysis, with minimal discrepancies, showed that countries in the region were identically ranked in terms of macroeconomic stability, as an isolated observed factor affecting competitiveness, and the overall ranking of the World Economic Forum, in all three observed points of time. This provided a positive answer to the posed research question of whether macroeconomic stability has a significant impact on the level of global competitiveness of national economies of the Western Balkans.

The fact is that the level of macroeconomic stability of the Western Balkan countries has not been at an enviable level in the previous period. Based on the conducted analysis, the Global economic crisis, regional conflicts and tensions, as well as internal problems regarding public finances and inefficient system of functioning of the economy were identified as the key factors that influenced the macroeconomic indicators. 


\section{References}

1. Bouzon, M., Govindan, K., Rodriguez, C. M. T., \& Campos, L. M. (2016), "Identification and analysis of reverse logistics barriers using fuzzy Delphi method and AHP”, Resources, Conservation and Recycling, Vol. 108, No 1, pp.182-197.

2. Buckley, P. J., Pass, C. L., \& Prescott, K. (1988), "Measures of international competitiveness: a critical survey", Journal of marketing management, Vol. 4, No 2, pp.175-200.

3. Corsetti, G., Kuester, K., Meier, A., \& Müller, G. J. (2013), "Sovereign risk, fiscal policy, and macroeconomic stability", The Economic Journal, Vol. 123, No 566, pp.99-132.

4. Čupić, M., Rao Tumala, V.M. and Suknović M. (2003), Odlučivanje formalni pristup, Fakultet organizacionih nauka, Beograd.

5. Dragašević, Z. (2015), Metode za ekonomske analize, Ekonomski fakultet, Podgorica.

6. Dumičić, M. (2019). Linkages Between Fiscal Policy and Financial (In) Stability. Journal of Central Banking Theory and Practice, 8 (1), 97-109.

7. Đurović, G. (2012), Evropska Unija i Crna Gora: politika proširenja, Ekonomski fakultet, Podgorica.

8. European union (1993), "Maastricht Treaty”, Official Journal C, 191, 29.

9. Jespersen, J. (2016), "Macroeconomic stability: Sustainable development and full employment", Research Paper from the Department of Social Sciences, Roskilde University, Vol.4, No 1, pp. 1-22.

10. Jocović, M., Milović, N., \& Melović, B. (2016), "Role of regulatory reforms for development and quality improvement of the construction sector in Montenegro". Journal of Applied Engineering Science, Vol. 14, No 1, pp.4653.

11. Jovanović, B., Filipović, J., \& Bakić, V. (2015), "Prioritization of manufacturing sectors in Serbia for energy management improvementAHP method", Energy Conversion and Management, Vol. 98, No 1, pp.225235.

12. Kersan-Skabic, I. (2017), "Is There a Debt-Overhang Problem in the European Union?', Economic Imbalances and Institutional Changes to the Euro and the European Union", International Finance Review, Vol. 18, No 1, pp.277-303.

13. Khalil, T., \& Ezzat, H. (2001), "Emerging new economy: Responsive policies", Global Forum on Management of Technology: Focus on the Arab Region, UNIDO, Vienna.

14. Kickert, W., \& Randma-Liiv, T. (2015), "Europe managing the crisis: The politics of fiscal consolidation", Routledge, pp.308. 
15. Kozarić, K., \& Žunić Dželihodžić, E. Ž. (2020). Effects of Macroeconomic Environment on Non-Performing Loans and Financial Stability: Case of Bosnia and Herzegovina. Journal of Central Banking Theory and Practice, 9(2), 5-17.

16. Krugman, P. (1994), "Competitiveness: a dangerous obsession”, Foreign Affairs., Vol. 73, No 2, pp.28-44.

17. Krugman, P. (2018), "Good enough for government work? Macroeconomics since the crisis", Oxford Review of Economic Policy, Vol. 34, No 1-2, pp.156168.

18. Mankiw, N. G. (2014). Principles of economics, Cengage Learning.

19. Milenković, I., Kalaš, B., \& Andrašić, J. (2017), "Macroeconomic determinants of economic growth in Serbia”, Facta Universitatis, Series: Economics and Organization, Vol. 14, No 2, pp.105-115.

20. Milović, N. (2012), Zajedničko tržište i politika konkurencije, Ekonomski fakultet, Podgorica.

21. Misztal, P. (2011), “The Relationship between Savings and Economic Growth in Countries with Different Level of Economic Development”, Finansowy Kwartalnik Internetowy e-Finanse, Vol. 7, No 2, pp.17-29.

22. Porter, M. (1990), The competitive advantage of nation", New York: Free Press.

23. Reuter, J. (1999), "Policy and economy in Macedonia”, Balkan Fortan, Vol. 1, No 3, pp.28-46.

24. Rice, M. E. (2017), "Building a state from a broken nation: the case of Bosnia-Herzegovina", Towson University Journal of International Affairs, Vol. L, No 2, pp.1-15.

25. Risteski, H. (2009). Assessing handicraft shadow economy in Macedonia. CEA Journal of Economics, 4(1).

26. Risti, L. C., Nicolaescu, C., \& Tăgăduan, D. (2013), "Budget Deficits Effects on Economic Growth", Journal of Economics and Business Research, Vol. 3, No. 2, pp.162-170.

27. Safiullin, M. R., Elshin, L. A., \& Prygunova, M. I. (2015), "Methodological approaches to assess the stability and global competitiveness of the regions under the macroeconomic instability conditions", Mediterranean Journal of Social Sciences, Vol. 6, No 3, pp.524-531.

28. Salman, D. M. (2014), "Mediating role of research and development on entrepreneurial activities and growth: Evidence from cross-country data”, World Journal of Entrepreneurship, Management and Sustainable Development, Vol. 10, No 4, pp.300-313.

29. Sanfey, P., Milatovic, J., \& Kresic, A. (2016), How the Western Balkans can catch up, European Bank for Reconstruction and Development. 
30. Siggel, E. (2006), "International competitiveness and comparative advantage: a survey and a proposal for measurement", Journal of Industry, competition and trade, Vol. 6, No 2, pp. 137-159.

31. Snowdon, B., \& Vane, H. R. (2005), Modern macroeconomics: its origins, development and current state, Edward Elgar Publishing.

32. Stojčić, N. (2012), “Teorijski temelji i mjerenje konkurentnosti”, Poslovna izvrsnost: znanstveni časopis za promicanje kulture kvalitete i poslovne izvrsnosti, Vol. 6, No 2, pp.143-165.

33. Topuzovski, T. (2009), From the imagining of the Balkans to the invention of the Western balkan, Reartikulacija, Ljubljana.

34. Vasylieva, T., Lyeonov, S., Lyulyov, O., \& Kyrychenko, K. (2018), "Macroeconomic stability and its impact on the economic growth of the country", Montenegrin Journal of Economics, Vol.14, No 1, pp.159-170.

35. Vijayakumar, J., Rasheed, A. A., \& Tondkar, R. H. (2009), "Foreign direct investment and evaluation of country risk: An empirical investigation", Multinational Business Review, Vol. 17, No 3, pp.181-204.

36. Vukčević, I., \& Jovović, R. (2020). The Quality of Public Finance in the Countries of South-East Europe. Journal of Central Banking Theory and Practice, 9(1), 169-184.

37. Wind, Y., \& Saaty, T. L. (1980), "Marketing applications of the analytic hierarchy process", Management science, Vol. 26, No 7, pp.641-658.

38. Woehrel, S. (2011), Kosovo: Current issues and US policy, Libra of Congfress Washington DC Congressional Research Service. 


\section{Appendix 1}

Image 1: Ranking of criteria by relevance

\begin{tabular}{|c|c|c|c|c|c|c|c|c|}
\hline 1. Choose & \multicolumn{5}{|c|}{ 2. Node comparisons with respect to $1.1 \mathrm{goal}$} & - & \multicolumn{2}{|l|}{ 3. Results } \\
\hline Noth arter & \multicolumn{5}{|c|}{ 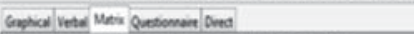 } & \multirow{2}{*}{\multicolumn{3}{|c|}{ hamitency oosese }} \\
\hline Choose Node $\leq y$ & \multirow{2}{*}{\multicolumn{5}{|c|}{$\begin{array}{l}\text { Comparisons wit "1.1 goal" node in " } 2 \text { criteria" cluster } \\
2.5 \text { credt rating is } 5 \text { smes more important than } 22 \text { public debt }\end{array}$}} & & & \\
\hline How & & & & & & 21 wodget & & 027264 \\
\hline \multirow{2}{*}{ Cluster. 1.gool } & heoviteng & $22,2000-$ & 23 mate- & 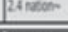 & 2500060 & 22 pidice & & 0.10949 \\
\hline & 21 aspe- & \multirow[t]{4}{*}{$\sqrt{\leftarrow 3}$} & $\leftarrow 5$ & $\leftarrow 7$ & $\uparrow 3$ & 23 inlat & & 006720 \\
\hline Choose Custer $\leq y$ & 22 atke & & \multirow[t]{3}{*}{$\longdiv { \leftarrow 2 }$} & $\leftarrow 3$ & $\uparrow 5$ & $\frac{24 \text { natorn }}{25 \text { coste }}$ & & $\frac{0.4178}{050907}$ \\
\hline 2 ottera & 2J elta- & & & \multirow[t]{2}{*}{$\leftarrow 2$} & $\longdiv { 1 6 }$ & & & \\
\hline & 24 notor- & & & & $\sqrt{18}$ & & & \\
\hline
\end{tabular}

Source: Constructed model in “Decision” program

\section{Appendix 2}

Image 2: AHP ranking list 2009.

\begin{tabular}{|c|c|c|c|}
\hline \multicolumn{4}{|c|}{ Here are the priorities. } \\
\hline Icon & Name & $\sqrt{\text { Normalized by Cluster }}$ & $\longdiv { \text { Limiting } }$ \\
\hline No Icon & $1.1 \mathrm{goal}$ & 0.00000 & 0.000000 \\
\hline No Icon & $\begin{array}{l}2.1 \text { budget surplus/ } \\
\text { deficit }\end{array}$ & 0.27264 & 0.136319 \\
\hline No Icon & $2.2 \%$ of public debt & 0.10949 & 0.054743 \\
\hline No Icon & $2.3 \%$ of inflations & 0.06720 & 0.033598 \\
\hline No Icon & $2.4 \%$ of national savings & 0.04178 & 0.020892 \\
\hline No Icon & 2.5 country's credit rating & 0.50890 & 0.254448 \\
\hline No Icon & 3.1 Montenegro & 0.31143 & 0.155713 \\
\hline No Icon & 3.2 Serbia & 0.12235 & 0.061176 \\
\hline No Icon & $3.3 \mathrm{BIH}$ & 0.13993 & 0.069967 \\
\hline No Icon & 3.4 Macedonia & 0.30633 & 0.153164 \\
\hline No Icon & 3.5 Albania & 0.11996 & 0.059980 \\
\hline
\end{tabular}

Source: Constructed model in "Decision" program 
Image 3: AHP ranking list 2013

\begin{tabular}{|c|c|c|c|}
\hline \multicolumn{4}{|c|}{ Here are the priorities. } \\
\hline Icon & Name & $\longdiv { \text { Normalized by Cluster } }$ & $\longdiv { \text { Limiting } }$ \\
\hline No Icon & $1.1 \mathrm{goal}$ & 0.00000 & $\longdiv { 0 . 0 0 0 0 0 0 }$ \\
\hline No Icon & $\begin{array}{l}2.1 \text { budget surplus/ } \\
\text { deficit }\end{array}$ & 0.27264 & 0.136319 \\
\hline No Icon & $2.2 \%$ of public debt & 0.10949 & 0.054743 \\
\hline No Icon & $2.3 \%$ of inflations & 0.06720 & 0.033598 \\
\hline No Icon & $2.4 \%$ of national savings & 0.04178 & 0.020892 \\
\hline No Icon & 2.5 country's credit rating & 0.50890 & 0.254448 \\
\hline No Icon & 3.1 Montenegro & 0.28534 & 0.142671 \\
\hline No Icon & 3.2 Serbia & 0.10685 & 0.053425 \\
\hline No Icon & $3.3 \mathrm{BIH}$ & 0.19529 & 0.097646 \\
\hline No Icon & 3.4 Macedonia & 0.21876 & 0.109381 \\
\hline No Icon & 3.5 Albania & 0.19375 & 0.096876 \\
\hline
\end{tabular}

Source: Constructed model in "Decision" program 
Image 4: AHP ranking list 2017

\begin{tabular}{|c|c|c|c|}
\hline \multicolumn{4}{|c|}{ Here are the priorities. } \\
\hline Icon & Name & $\longdiv { \text { Normalized by Cluster } }$ & Limiting \\
\hline No Icon & $1.1 \mathrm{goal}$ & 0.00000 & 0.000000 \\
\hline No Icon & $\begin{array}{l}2.1 \text { budget surplus/ } \\
\text { deficit }\end{array}$ & 0.03195 & 0.015973 \\
\hline No Icon & $2.2 \%$ of public debt & 0.11104 & 0.055521 \\
\hline No Icon & $2.3 \%$ of inflations & 0.26251 & 0.131256 \\
\hline No Icon & $2.4 \%$ of national savings & 0.06715 & 0.033573 \\
\hline No Icon & 2.5 country's credit rating & 0.52735 & 0.263677 \\
\hline No Icon & 3.1 Montenegro & 0.23343 & 0.116715 \\
\hline No Icon & 3.2 Serbia & 0.32315 & 0.161575 \\
\hline No Icon & $3.3 \mathrm{BIH}$ & 0.15732 & 0.078658 \\
\hline No Icon & 3.4 Albania & 0.28611 & 0.143053 \\
\hline
\end{tabular}

Source: Constructed model in "Decision" program 